\title{
IMPACTS OF MANAGEMENT ACCOUNTING IN MICROENTERPRISES ENTERPRISES: A SYSTEMATIC REVIEW
}

\author{
Ali Alfartoosi ${ }^{1}$, Mohd Abdullah Jusoh ${ }^{1}$, Harith Yas ${ }^{2}$ \\ ${ }^{1}$ University Pendidikan Sultan Idris (UPSI), Tanjong Malim, Malaysia, \\ Tanjong Malim, Perak Darul Ridzuan 35900. \\ ${ }^{2}$ Azman Hashim International Business School, Universiti Teknologi Malaysia, \\ Johor Bahru, Johor 54100, Malaysia
}

\begin{abstract}
The current study sought to explore and understand how te use of management accounting techniques in microenterprises affects those entities. Precisely, the study focused on examining how the application of management accounting tools affects microenterprises. The research methodology employed in this study involved collecting data from journals, articles, publications, and relevant empirical studies. The collected data was analyzed through common themes generated from the project documentation. The results of the study depicted that management accounting practices such as cost system analysis, budgeting and providing accounting information improved the performance of microenterprises. Besides, these tools were evidently supported as essential elements in decision making as far micro enterprises are concerned. The study recommends that microenterprises should focus on budgeting, cost system analysis and using accounting information as their key drivers in decision making. Besides, the study proposed further research to be done with empirical studies to gauge whether the conclusions drawn will be the same.
\end{abstract}

Keywords-Management

Accounting, Microenterprises, Small and Medium sized firms, costing system; budgeting; information for decision making;

\section{INTRODUCTION}

The contemporary economy is fundamentally based on small microenterprises as the main drivers of the labor market at both local and national levels. Berrone et al., (2014) notes that microenterprises accounts for the largest share of economic units in any given economy. For instance, microenterprises in a country such as Mexico accounts for $96.3 \%$ of the total economic units in the country with an employment of
$40 \%$ of the national formal employment (Institute National, 2016). According to Berone et al., (2014), the current literature has overlooked the importance of microenterprises in many areas. In Saudi Arabia, microenterprises dominate Dubai's economy. The Dubai Department of Economic Development reported that microenterprise generates nearly $40 \%$ of the economy's value added and $42 \%$ of employment (Dubai Department of Economic Development, 2018).

The need for accountancy in management styles forms the basics of operations in contemporary microenterprises. According to Schwarze (2008), many microenterprises are led and managed/owned by managers who lack the necessary skills, clear processes, operational efficiencies, access to financial resources and professionalism advocated by the theories of management accounting. This leads to more widened gap between microenterprises and the well-established firms due to their abilities in capital and human resources (Lavia and Hiebl, 2015). However, imparting knowledge of management accounting to the managers/owners and especially the maintenance of financial statement records can be the initial stages of developing skills to make informed financial decisions.

The current available literature on the use of management accounting techniques in microenterprises as a tool in decision making and management control is inadequate. Most of the modern microenterprises fails to understand that management accounting involves the use of various tools as ways of controlling elements pertaining to decision making and financial investments. According to Armitage et al., (2016), most of the management accounting tools used in cash management includes but not limited to cash balance in bank accounts, cash conversion cycles and operating cash flow. Most of the existing literature has overly ignored microenterprises or often used it as a bloc under small and medium sized 


\section{International Journal of Engineering Applied Sciences and Technology, 2021 Vol. 6, Issue 1, ISSN No. 2455-2143, Pages 445-451 \\ Published Online May 2021 in IJEAST (http://www.ijeast.com)}

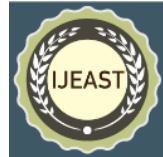

enterprises. However, some authors such as Alatter et al., (2009) and Berrone et al., (2014) who noted that it is important to study micro and small enterprises separately in such a way that specific applications, processes and recommendation can be drawn from them.

According to Esparza et al., (2019) argues that micro and small business accounts for an arguably relevant research opportunities towards the path to understand how management accounting techniques are applied in both small and large corporations. As a result, the current study seeks to understand the impacts of applying management accounting techniques in microenterprises. The study will analyze the advantages which firms which apply management accounting techniques accrue over those who do not. The study to contribute to fill in the already mentioned gap in management accounting research, focusing on micro enterprises. the central purpose of the research is to analyze how micro and small firms apply management accounting tools. This objective will be achieved through a systematic review of the existing literature.

\section{LITERATURE REVIEW}

The application of management accounting tools and techniques has been discussed in various contexts. For instance, authors such as Burns et al., (2013) discuss how management accounting can be applied in small and medium sized enterprises. According to Anderson and Samuelsson (2016), management accounting has been defined as the provision of information to business management for decision making and assisting enterprises in attaining their organizational objectives through efficiency building. According to Shields (2015) management accounting entails those topics which covers elements related to management accounting information such as budgets, performance measurement tools, product costs and characteristics of Management Accounting Information. Besides, Shields (2015) also notes that management accounting techniques can also entail management practices such as carrying out budgeting, perfemonace measuring, evaluation and quality management practices. The current literature review reflects on the adoption of a wide variety of management accounting concepts and techniques such as budgeting, planning, performance evaluation, costing, decision making systems and strategic analysis as essential tools for microenterprises (Lavia and Hiebl, 20`15).

Shields and Shelleman (2016) carried out a study to cement the place and role played by analysis systems and approaches for planning and administrative control in management accounting. Although the existing literature is large and adequate on the use of management accounting, there is very little research on small business, and even less in microeconomics with such research being disjointed and contradictory (Shelleman, 2016). For the most of the existing literature, studies have interpretively focused on microenterprises with small and micro firms and medium-sized companies. Despite the noticed gap and lack of reference to microenterprises, there are distinct differences between small and medium-sized enterprises; and it has been noticed as Grande et al., (2011) notes that most studies have focused on medium-sized firms. The difference still remains large when microenterprises are considered. the author notes that the study included microenterprises because many authors who study SMEs opt to eliminate some groups all together because they are less differentiated or maybe too small to remain stable, consistent, and depended on the owner/manager.

Husin and Ibrahim (2014) carried out a study to establish the role management accounting on the performance of small and medium sized enterprises in East Malaysia. The paper sought establish how accounting firms can be of importance when it's techniques and tools of management accounting are used microenterprises to make informed decisions. The paper was guided by a conceptual framework based on the relationship of microenterprise functions and management accounting techniques. The results of the study depicted that there was a significant relationship between performance of microenterprises and the application of management accounting tools.

Small firms and microenterprises are generally troubled by the use of accounting-financial information which is a key element of management accounting. Broccardo (2014) argues that despite the fact that small and microenterprises generates financial information for tax purposes, they rarely or never use this information in making informed decisions. The authors argue that most of the insights obtained from the financial statements of many small and microenterprises is either inadequate, inappropriate or both. Most of modern microenterprises applies very little or fail to use any of the management accounts tools and techniques due to the inituative and skill-based administrations (Broccardo, 2014). According to Dyt and Halabi (2007), one of the most essential factors of failure among micro and small firms is financial mismanagement. This challenge is fueled by the outright misuse of the firm's accounting and financial information coupled with the lack of clear goals and objectives. Despite the rare use of management 


\section{International Journal of Engineering Applied Sciences and Technology, 2021 \\ Vol. 6, Issue 1, ISSN No. 2455-2143, Pages 445-451 \\ Published Online May 2021 in IJEAST (http://www.ijeast.com)}

accounting tools in microenterprises, some authors such as Peters and Buhalis (2004) argues that small and medium sized enterprises tend to use financial information as a tool in decision making. The need to use management accounting tools in microenterprises is the same irrespective of the firm's geographical location. However, the application and use of management accounting tools and techniques is believed to be hindered by inadequate human and financial resources, absence of administrative capacity, poor strategic planning and the notion that accounting systems denies firms the much-needed flexibility in the microenterprise industry (Lavia and Hiebl, 2015).

The current literature fails to agree on the effect of an enterprise's size and the use of management accounting tools. In a study conducted by Danielson and Scott (2006) established that generally, microenterprises were unlikely to use management accounting unlike small and medium sized enterprises. The same trend $\mathrm{d}$ was witnessed by Chand and Dahuya (2010) who in their respective studies established that there was no differences in the use of management accounting tools in small and medium sized enterprises. In another study conducted by Neubauner et al., (2012), it was found that small and medium sized enterprises rarely used management accounting tools but when segmented across micro. small and medium sized enterprises, microenterprises were found to rarely use management accounting techniques. Contrary to this study, a recent study carried out by Shield and Shelleman (2016) found that microenterprises used management accounting tools frequently. This was echoed by Allater et al., (2009) who noted that microenterprises use management accounting tools informally without keeping records or even without being aware of it.

Previously conducted research has provided enough evidence to prove that the application of management accounting tools improves perfomance and control in a firm. In the study conducted by lavia and Hiebl (2015), it was established that small and medium sized firms which used management accounting registered improved performance and long-term development. Additionally, the application of management accounting tools has also been documented to improve rate of Interest (ROI) in microenterprises while Esparza (2016) found that the application and use of cash flow-related tools had an impact on performance. As a result, it is expected that those microenterprises, small and medium firms which use management accounting tools have improved performance.

The definition of microenterprises differs from one region to the next (OECD, 2010). The major differences in the definition of a microenterprises in this countries and regions is based on the number of employees and revenues generated Lavia and Hiebl, 2015). However, this paper is based on the European Commission 2010 statement. The Dubai definition of Small and microenterprises is based on turn over and employment abilities. For instance, microenterprises in Dubai are categorized as those firms with less than nine employees and a turnover of $9 \mathrm{mn}$ (Dubai, 2014).

\section{METHODODLOGY}

\subsection{Systematic Review}

The current study utilized a systematic review design where various databases were screened for relevant sources. Majorly, articles to be reviewed were obtained by searching Google Scholar, Ebscohot and Scopus. The literature search was focused on identifying papers published between 2015 to 2021 and were relevant to the topic of study. Given that the existing literature on management accounting on microenterprises is limited, studies which discussed small, medium and microenterprises as different elements rather than a block were included. The reference lists of the identified papers were further screened to identify chances of any relevant papers that might have been omitted in the initial search. Besides, the title of the reference lists of the identified papers were further screened separately to identify relevant papers that might have been omitted from the database search.

\subsection{Inclusion Criterion}

The current study included all sources that were government publications, reports, peer reviewed journals, and ecological research papers that discussed the role and importance of mismanagement accounting in small, middle and microenterprises as different entities.

\subsection{Data collection}

The current study used data extracted from the studies that met the inclusion criteria. The analyzed data pertained to the study design, setting, definition of outcomes and measurement, the source populations and the quality of the methodological designs were considered.

\section{RESULTS}

After reviewing the existing literature, 90 studies published between 2015 to 2021 on the role of management accounting in small, medium and microenterprises were identified. Further screening of 
International Journal of Engineering Applied Sciences and Technology, 2021

Vol. 6, Issue 1, ISSN No. 2455-2143, Pages 445-451

Published Online May 2021 in IJEAST (http://www.ijeast.com)

the titles and abstracts produced only 12 studies for full text review. The rest of the studies were excluded after reviewing each full text. Further, two sources were excluded from the list because their data analysis lacked any statistical description. However, one study was included after screening the reference lists of the chosen papers. Finally, 11studies were included in the final review. Summary of the overall literature search is presented in figure 4.1 below.

Figure 4.1. Summary of the Literature Search

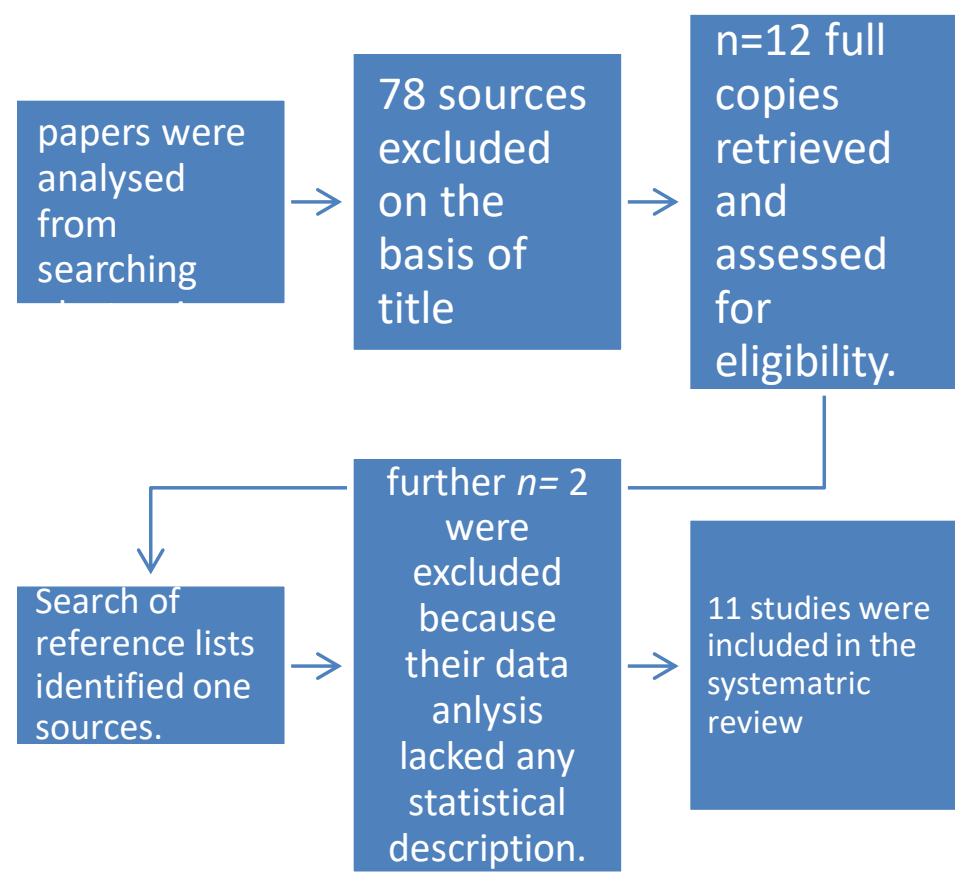

\subsection{Characteristics of the Studies Included}

The research papers included in the current study were either done in Saudi Arabia, United Arab Emirates, the United States or any English-speaking European nation. This study focused on those nations which might have close Small, medium and Micro enterprises similar to the ones found in Saudi Arabia. Only two of the studies were rated high in their methodology strategies following the Newcastle Ottawa Scale (NOS0 (1-7) (Wells et al., 2019).

Table 4.1. Characteristics of the Studies Included

\begin{tabular}{|c|c|c|}
\hline $\begin{array}{c}\text { Year of } \\
\text { Publicati } \\
\text { on }\end{array}$ & Selected Area of Study & $\begin{array}{c}\text { Type of } \\
\text { study }\end{array}$ \\
\hline
\end{tabular}

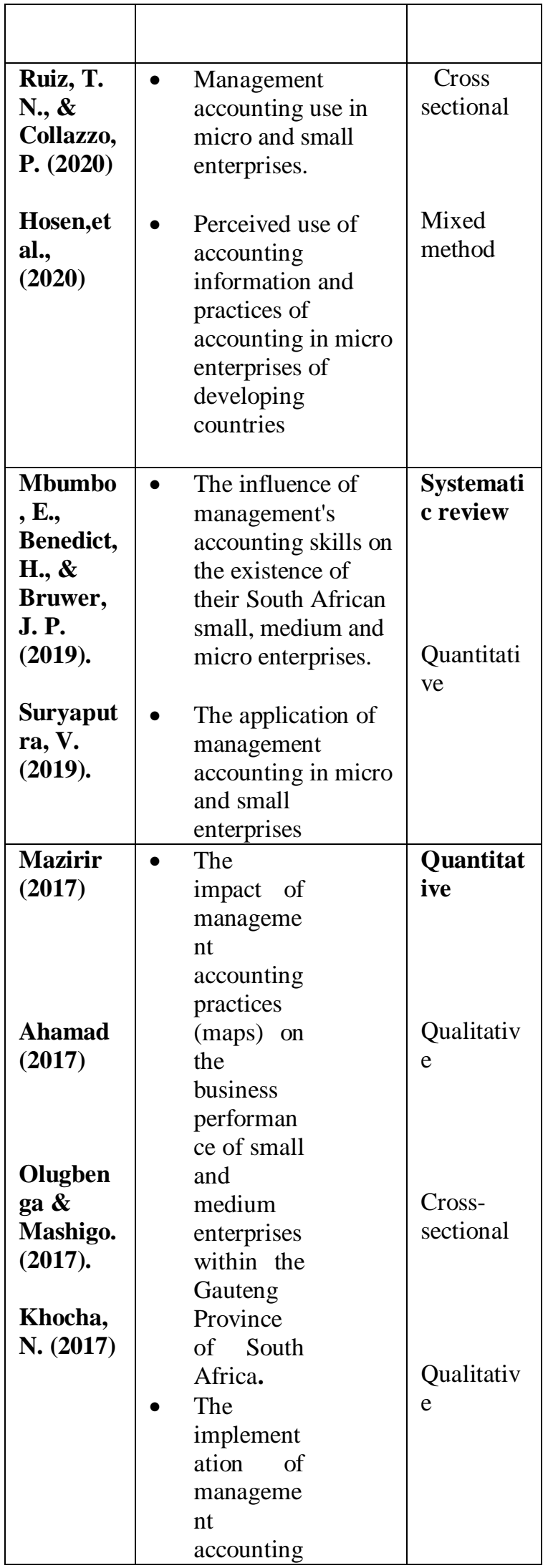




\begin{tabular}{|c|c|c|}
\hline & $\begin{array}{l}\text { practice } \\
\text { and its } \\
\text { relationshi } \\
\text { p with } \\
\text { performan } \\
\text { ce in Small } \\
\text { and } \\
\text { Medium } \\
\text { Enterprise } \\
\text { s sector. } \\
\text { The } \\
\text { impact of } \\
\text { microfinan } \\
\text { ce on } \\
\text { microenter } \\
\text { prises. } \\
\text { The } \\
\text { organizati } \\
\text { on of } \\
\text { manageme } \\
\text { nt accounting } \\
\text { at small } \\
\text { enterprises } \\
\text { in Ukraine. }\end{array}$ & \\
\hline $\begin{array}{c}\text { Shields \& } \\
\text { Shellema } \\
\text { n (2016) } \\
\text { Bruwer, } \\
\text { J. P., \& } \\
\text { Coetzee, } \\
\text { P. (2016) }\end{array}$ & $\begin{array}{l}\text { Management } \\
\text { accounting systems } \\
\text { in micro-SMEs. } \\
\text { A literature review } \\
\text { of the } \\
\text { sustainability, the } \\
\text { managerial conduct } \\
\text { of management and } \\
\text { the internal control } \\
\text { systems evident in } \\
\text { South African } \\
\text { small, medium and } \\
\text { micro enterprises. }\end{array}$ & $\begin{array}{l}\text { Quantitati } \\
\text { ve } \\
\text { Systemati } \\
\text { c review }\end{array}$ \\
\hline $\begin{array}{c}\text { Lavia \& } \\
\text { Hiebl, } \\
\text { (2015) }\end{array}$ & $\begin{array}{l}\text { - Management } \\
\text { accounting in small } \\
\text { and medium-sized } \\
\text { enterprises: current } \\
\text { knowledge and } \\
\text { avenues for further } \\
\text { research }\end{array}$ & $\begin{array}{l}\text { Systemati } \\
\text { c review }\end{array}$ \\
\hline
\end{tabular}

\section{DISCUSSION}

The aim of the current research was to investigate the impact of management accounting techniques and tools on microenterprises. The results of the study focus on the various themes that arose from the literature analysis. The papers were analyzed to provide insights on the five most common management accounting practices, that is, costing system, budgeting, performance evaluation, information for decision making and strategic analysis.

\subsection{Costing System and Business Performance}

Costing system emerged as one of the major tools that has a positive influence on business performance. This tool emerged significantly as a predictor of business control, and performance. Six studies indicated that application of costing system in microenterprises proved essential in monitoring how specific goals and objectives faired in the long run. The study results were similar to the conclusions drawn by Mazirir et al., (2017) who found that costing systems such as activity-based costing led to high levels in performance.

\subsection{Budgeting}

In the thematic analysis of the literature, budgeting emerged as an essential management accounting tool that can enhance performance in microenterprises. Four studies reported that firms which applied budgeting as a management accounting tool reported higher performance rates. In the study conducted by Bruwer and Coetzee, (2016), the impact of budgeting on performance in micro, small and medium sized enterprises in south Africa. The results from the study by Bruwer and Coetzee (2016), Lavia \& Hiebl (2015), provided significant support to the positive impact of budgeting on microenterprises.

\section{3: Accounting Information}

The current findings of the study established that accounting information was an essential management accounting tool in decision making. This was depicted by the existing literature researchers such as Kocha (2017) established that information accounting forms the basics in not only microenterprises but also SME's and large corporations. However, some authors such as Mazirir, (2017) established that information was not a key tool in microenterprises as it is the case with large corporations. the authors reported that this was different because microenterprises and small firms operates different.

\subsection{LIMITATIONS AND DIRECTIONS TO FUTURE RESEARCH}




\section{International Journal of Engineering Applied Sciences and Technology, 2021 \\ Vol. 6, Issue 1, ISSN No. 2455-2143, Pages 445-451 \\ Published Online May 2021 in IJEAST (http://www.ijeast.com)}

The current study offers significant insights and contributions to the academic fraternity and practice despite the few limitations encountered. First, the articles reviewed were strictly from the Arab and English-speaking countries; perhaps, if it was collected from other regions it would produce different results. Additionally, since the current study was a qualitative systematic review, future studies should be empirical so as to offer significant insights on the role of management accounting techniques in microenterprises. Also, future research can also extend the framework of the current study by including other management accounting variables to understand their impact on microenterprises.

\section{CONCLUSION}

The current study contributes immensely to the body of knowledge on management accounting through a critical analysis of the existing literature and methodologies. this renders the paper as a viable source of information that can be used by researchers on future studies. Besides, the current study depicts that tools and techniques of management accounting such as budgeting, cost system and information are essential for decision making and improving microenterprises performance. The findings of the study also depict that those microenterprises which engage in management accounting practices enhances their overall performance. Theoretically, the current study offers essential contributions to the concept of management accounting by systematically and methodologically examining the impact of management accounting tools.

\section{REFERENCES}

1 Ahmad, K. (2017). The implementation of management accounting practice and its relationship with performance in Small and Medium Enterprises sector. International Review of Management and Marketing, 7(1).

2 Alattar, J. M., Kouhy, R., \& Innes, J. (2009). Management accounting information in micro enterprises in Gaza. Journal of Accounting \& Organizational Change.

3 Alsaud, A. B., Yas, H., \& Alatawi, A. (2021). A New Decision-Making Approach for Riyadh makes up 50 percent of the nonoil economy of Saudi Arabia. Journal of Contemporary Issues in Business and Government, 27(1), 3376-3392.

4 Armitage, H., Webb, A. and Glynn, J. (2016), "The use of management accounting techniques by small and medium-sized enterprises: a field study of Canadian and Australian practice", Accounting Perspectives, Vol. 15 No. 1, pp. 31-69.

5 Berrone, P., Gertel, H., Giuliodori, R., Bernard, L. and Meiners, E. (2014), "Determinants of performance in microenterprises: preliminary evidence from Argentina", Journal of Small Business Management, Vol. 52 No. 3, pp. 477-500.

6 Bruwer, J. P., \& Coetzee, P. (2016). A literature review of the sustainability, the managerial conduct of management and the internal control systems evident in South African small, medium and micro enterprises.

7 Burns, J., Quinn, M., Warren, L. and Oliviera, J. (2013), Management Accounting, McGraw-Hill Higher Education, London

8 Datar, S. M., Epstein, M. J., \& Yuthas, K. J. (2009). Management accounting and control: Lessons for and from the world's tiniest businesses. Strategic finance.

9 Dubai Department of Economic Development. (2018). The Report: Entrepreneurship helps drive Dubai's economy. Retrieved from: https://oxfordbusinessgroup.com/analysis/g rassroots-growth-entrepreneurship-helpsdrive-economy

10 Dubai, S. (2014). The state of small and medium enterprises (SMEs) in Dubai. Dubai, Mohammed Bin Rashid Establishment for SME Development (Dubai SME).

11 Esparza, J., García, D. and Duréndez, A. (2016), "The effect of accounting information systems on the performance of Mexican micro, small and medium-sized family firms: an exploratory study for the hospitality sector", Tourism Economics, Vol. 22 No. 5, pp. 1104-1112.

12 Grande, E., Estebanez, R. and Colomina, C. (2011), "The impact of accounting information systems (AIS) on performance measures: empirical evidence in Spanish SMEs", International Journal of Digital Accounting Research, Vol. 11, pp. 25-43.

13 Hosen, M. Z., Rahmana, M. T., \& ur Rashidb, M. M. (2020). Perceived use of accounting information and practices of accounting in micro enterprises of developing countries. Journal of Accounting and Management Information Systems, 19(4), 682-706. 


\section{International Journal of Engineering Applied Sciences and Technology, 2021 \\ Vol. 6, Issue 1, ISSN No. 2455-2143, Pages 445-451 \\ Published Online May 2021 in IJEAST (http://www.ijeast.com)}

14 Husin, M. A., \& Ibrahim, M. D. (2014). The role of accounting services and impact on small medium enterprises (SMEs) performance in manufacturing sector from East Coast Region of Malaysia: A conceptual paper. Procedia-Social and Behavioral Sciences, 115, 54-67.

15 Hussain, H. I., \& Hadi, A. R. A. (2019). Emerging Economic and Business Trends in Developing Markets: EDITORIAL LETTER. Contemporary Economics, 13(3), NA-NA.

16 Instituto Nacional de Estadística y Geografía (2016), "Encuesta Nacional sobre Productividad y Competitividad de las Micro, Pequeñas y Medianas Empresas (ENAPROCE) 2015", available at: www.inegi.org.mx/est/

contenidos/proyectos/encuestas/establecimi entos/otras/enaproce/default_t.aspx (accessed 15 September 2018).

17 Khocha, N. (2017). The organization of management accounting at small enterprises in Ukraine. Baltic Journal of Economic Studies, 3(4).

18 Khudhair, H. Y., \& Mardani, A. (2021). The Major Issues Facing Staff in Islamic Banking Industry. International Journal of Economics and Management Systems, 6.

19 Khudhair, H. Y., \& Mardani, A. (2021). The Positive Role of the Tourism industry for Dubai City in the United Arab Emirates. International Journal of Economics and Management Systems, 6.

20 Khudhair, H. Y., Jusoh, A., Mardani, A., \& Nor, K. M. (2019). Quality Seekers as Moderating Effects between Service Quality and Customer Satisfaction in Airline Industry. International Review of Management and Marketing, 9(4), 74.

21 Lavia López, O., \& Hiebl, M. R. (2015). Management accounting in small and medium-sized enterprises: current knowledge and avenues for further research. Journal of Management Accounting Research, 27(1), 81-119.

22 Lavia, L. and Hiebl, M. (2015), "Management accounting in small and medium-sized enterprises: current knowledge and avenues for further research", Journal of Management Accounting Research, Vol. 27 No. 1, pp. 81119.

23 Maziriri, E. T. (2017). The impact of management accounting practices (maps) on the business performance of small and medium enterprises within the Gauteng Province of South Africa.

24 Mbumbo, E., Benedict, H., \& Bruwer, J. P. (2019). The influence of management's accounting skills on the existence of their South African small, medium and micro enterprises. International Journal of Education Economics and Development, 10(3), 323-334

25 OECD (2010), SMEs, Entrepreneurship, and Innovation, OECD, Paris.

26 Olugbenga, S., \& Mashigo, P. (2017). The impact of microfinance on microenterprises. Investment management and financial innovations, (14,№ 3), 82-92.

27 Ruiz, T. N., \& Collazzo, P. (2020). Management accounting use in micro and small enterprises. Qualitative Research in Accounting \& Management.

28 Samuelsson, J., Andersén, J., Ljungkvist, T. and Jansson, C. (2016), "Formal accounting planning in SMEs: the influence of family ownership and entrepreneurial orientation", Journal of Small Business and Enterprise Development, Vol. 23 No. 3, pp. 691-702.

29 Schwarze, C. (2008), "Involving the accounting profession in the development of financial management skills of microenterprise owners in South Africa", Meditari Accountancy Research, Vol. 16 No. 2, pp. 139-151.

30 Shields, J., \& Shelleman, J. M. (2016). Management accounting systems in microSMEs. Journal of Applied Management and Entrepreneurship, 21(1), 19.

31 Shields, M. (2015), "Established management accounting knowledge", Journal of Management Accounting Research, Vol. 27 No. 1, pp. 123-132

32 Suryaputra, V. (2019). The application of management accounting in micro and small enterprises. In Global Competitiveness: Business Transformation in the Digital Era (pp. 3-7). Routledge. 